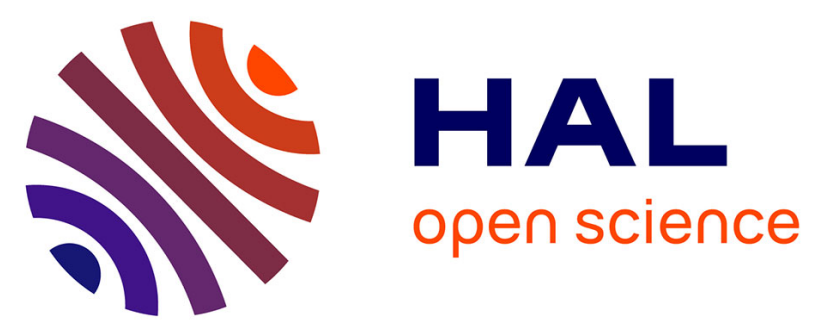

\title{
Family trios analysis of common polymorphisms in the obestatin/ghrelin, BDNF and AGRP genes in patients with Anorexia nervosa: Association with subtype, body-mass index, severity and age of onset.
}

Roland M. Dardennes, Philippe Zizzari, Virginie Tolle, Christine Foulon, Amélie Kipman, Lucia Romo, Dana Iancu-Gontard, Claudette Boni, Pierre-Marie Sinet, Marie-Thérèse Bluet-Pajot, et al.

\section{- To cite this version:}

Roland M. Dardennes, Philippe Zizzari, Virginie Tolle, Christine Foulon, Amélie Kipman, et al.. Family trios analysis of common polymorphisms in the obestatin/ghrelin, BDNF and AGRP genes in patients with Anorexia nervosa: Association with subtype, body-mass index, severity and age of onset.. Psychoneuroendocrinology, 2007, 32 (2), pp.106-113. 10.1016/j.psyneuen.2006.11.003 . inserm-00122530

\section{HAL Id: inserm-00122530 https://www.hal.inserm.fr/inserm-00122530}

Submitted on 3 Jan 2007

HAL is a multi-disciplinary open access archive for the deposit and dissemination of scientific research documents, whether they are published or not. The documents may come from teaching and research institutions in France or abroad, or from public or private research centers.
L'archive ouverte pluridisciplinaire HAL, est destinée au dépôt et à la diffusion de documents scientifiques de niveau recherche, publiés ou non, émanant des établissements d'enseignement et de recherche français ou étrangers, des laboratoires publics ou privés. 


\section{HAL author manuscript}

Family trios analysis of common polymorphisms in the obestatin/ghrelin, BDNF and AGRP genes in patients with Anorexia nervosa : association with subtype, body-mass index, severity and age of onset.

Roland M DARDENNES*1\&2, Philippe ZIZZARI*2, Virg inie TOLLE ${ }^{2}$, Christine FOULON ${ }^{3}$, Amélie KIPMAN ${ }^{4}$, Lucia ROMO ${ }^{5}$, Dana IANCU-GONTARD², Claudette BONI ${ }^{6}$, Pierre-Marie SINET $^{2}$, Marie Thérèse BLUET ${ }^{2}$, Bruno ESTOUR ${ }^{7}$, Marie-Christine MOUREN ${ }^{488}$, JulienDaniel GUELFI ${ }^{1}$, Frédéric ROUILLON ${ }^{1}$, Philip GORWOOD ${ }^{5 \& 8}$, Jacques EPELBAUM ${ }^{2}$

${ }^{1}$ Université Paris-Descartes, Faculté de Médecine, Hôpital Sainte-Anne, 1 rue Cabanis 75674 Paris Cedex 14 FRANCE

2 INSERM, UMR 549, Centre Paul Broca, 2 ter rue d'Alésia 75014 Paris France

${ }^{3}$ Hôpital Sainte-Anne, 1 rue Cabanis 75674 Paris Cedex 14 FRANCE

${ }^{4}$ Université Paris 7, Faculté de Médecine, Hôpital Robert Debré, 48 boulevard Sérurier 75935 Paris cedex 19

${ }^{5}$ Université Paris 7, Faculté de Médecine, Hôpital Louis Mourier 178, rue des Renouillers 92701 COLOMBES CEDEX

${ }^{6}$ INSERM, U288, Faculté Pitié-Salpêtrière - 91 Bd de l'Hôpital 75013 Paris

${ }^{7}$ Université Jean Monnet, Hôpital Bellevue, 42055 Saint-Etienne Cedex 2

${ }^{8}$ INSERM, U675, Faculté Xavier Bichat, 16 rue Henri Huchard 75018 Paris

* Each of these authors contributed equally to this work

Corresponding author: Jacques EPELBAUM, Centre Paul Broca, INSERM, U549, 2 ter rue d'Alésia 75014 Paris France. Tél : +3314078 92 82. Fax : +331458072 93. Email : epelbaum@broca.inserm.fr

Running title : anorexia trios, preproghrelin \& AGRP 


\section{Abstract :}

Anorexia Nervosa affects $0.3 \%$ of young girls with a mortality of $6 \%$ per decade and is strongly familial with genetic factors. Ghrelin is an upstream regulator of the orexigenic peptides NPY and AgRP and acts as a natural antagonist to leptin's effects on NPY/AgRPexpressing neurons, resulting in an increase in feeding and body weight. Obestatin which counteracts ghrelin action on feeding is derived from the same propeptide than ghrelin. BDNF has been involved in body weight regulation and its Val66Met polymorphism associated with AN. We therefore re-investigated the association between AN and the Leu72Met and GIn90Leu polymorphisms of the prepro-ghrelin/obestatin gene, the Ala67Thr polymorphism of AgRP and the Val66Met polymorphism of BDNF taking into account clinical subtypes (restrictive - ANR - and bingeing/purging - ANB - subtypes). Family trios study of these 4 single nucleotide polymorphisms were performed in 114 probands with anorexia nervosa and both their parents recruited in two specialized French centers. A transmission disequilibrium was observed for the Leu72Met SNP of the preproghrelin gene and for the Ala67Thr SNP of the AgRP gene. When stratified by clinical subtype, these two polymorphisms were preferentially transmitted for the trios with a bingeing/purging proband. An excess of transmission of the GIn90Leu72 preproghrelin/obestatin haplotype in patients with anorexia nervosa was observed. These results do not provide evidence for a preferential transmission of the 66 Met allele of BDNF but support the hypothesis that ghrelin and AGRP polymorphisms confers susceptibility to AN. Further simultaneous analysis of genetic variants of the biological determinants of energy metabolism and feeding behavior in very large populations should contribute to the understanding of the high degree of heritability of eating disorders and to the 
description of pathophysiological patterns leading to life-threatening conditions in a highly redundant system.

Keywords : anorexia nervosa, ghrelin, AGRP, BDNF, trios analysis, genes 


\section{Introduction}

Anorexia nervosa (AN) is a chronic disease characterized by progressive cachexia in individuals, mainly women, continuously obsessed with weight gain and engaging in behaviours designed to perpetuate weight loss in spite of their obvious emaciation. The prevalence has been reported to be $0.3 \%$ for young females with a peak age of onset between 15 and 19 years old (Hoek and van Hoeken, 2003). Mortality is estimated to be 6 \% per decade (Sullivan, 1995). The course of AN is often marked by crossover to bulimia nervosa, mainly occurring within the first 5 years (Tozzi et al., 2005). Family and twin studies have consistently demonstrated that AN is strongly familial and that the observed familiality is due primarily to genetic factors (Gorwood et al., 2003). These findings led to a great increase in molecular genetic studies (Klump and Gobrogge, 2005). Most studies focused on the serotonin system, but other candidate genes have been studied, including genes involved in the regulation of feeding and energy (e.g. neuropeptide $Y$, leptin, agouti-related protein (AgRP) and Brain Derived Neurotrophic Factor (BDNF), (cf. Klump and Gobrogge (2005)). The role of these genes in the etiology of AN is still hypothetic as these studies have rarely been replicated.

Another candidate gene is the gene encoding for ghrelin, a strong orexigenic and adipogenic peptide in mammals (Nakazato et al., 2001). Inhibiting ghrelin-receptor expression in the hypothalamus of transgenic rats by expressing anti-sense ghrelin receptor mRNA decreases food intake, and body fat mass (Shuto et al., 2002), suggesting the importance of the hypothalamic ghrelin receptors in energy homeostasis. Ghrelin is an upstream regulator of the orexigenic peptides NPY and AgRP and acts as a natural antagonist to leptin's effects on NPY/AgRP-expressing neurons, resulting in an increase in 
feeding and body weight (Zigman and Elmquist, 2003). Human ghrelin is a 28-amino acid peptide, its gene is located on chromosome 3p25-26 and consists of four exons and three introns (Wajnrajch et al., 2003). IV administration of ghrelin to healthy humans increases subjective appetite and energy intake from a buffet lunch by $28 \%$ (Wren et al., 2001). Plasma ghrelin levels are highly elevated in patients with AN and return to normal after weight gain (Otto et al., 2001; Tolle et al., 2003). It has been shown that the bingeeating/purging subtype group had higher levels than the restricting subtype and still had higher levels than the controls after weight gain (Tanaka et al., 2004). Moreover, carriers of the Met72 allele of the preproghrelin/ghrelin gene may be protected against fat accumulation and associated metabolic comorbidities in the general population and in obese populations as well (Ukkola et al., 2002). Obestatin, a recently discovered peptide derived from the same prepropeptide (Zhang et al., 2005), may explain the lack of obvious phenotype in adult ghrelin -/- mice as obestatin exerts ghrelin-opposite anorexigenic effects by decreasing food intake, gastric emptying, jejunal motility, and weight gain. The Gln90Leu polymorphism of the preproghrelin gene is caused by a SNP which lies in the region coding for obestatin. A recent study, performed on 529 trios recruited from seven european countries indicated different genotype and allele frequency distribution in this polymorphism according to the country (Cellini et al., 2006). We therefore re-investigated the association between AN and the Leu72Met and GIn90Leu polymorphisms of the prepro-ghrelin gene (Met72GHREL and Leu90OBE), taking into account clinical subtypes (restrictive - ANR - and Bingeing/purging - ANB - subtypes). Moreover, since ghrelin regulates AgRP orexigenic neurons and the Ala67Thr polymorphism of AgRP (Thr67AGRP) has been associated with AN (Vink et al., 2001), and also since BDNF has been involved in body weight regulation and its Val66Met 
polymorphism (Met66BDNF) associated with AN (Ribases et al., 2003; Ribases et al., 2004; Hashimoto et al., 2005; Ribases et al., 2005), these polymorphisms were analysed.

\section{Methods}

\section{Subjects}

114 probands with anorexia nervosa and both their parents were recruited in two French Centers specialized in eating disorders (Centre Hospitalier Saint Anne (49 trios ) and Hôpital Robert Debré (65 trios)). All patients fulfilled DSM-IV (American Psychiatric Association. and American Psychiatric Association. Task Force on DSM-IV., 1994) criteria for anorexia nervosa, the diagnosis being based on the Diagnostic Interview for Genetic Studies (Nurnberger et al., 1994). All probands were classified as restricting or bingeeating/purging subtype. Diagnosis was blind to genotype. Clinical information included age of onset (defined as the year the weight loss started), lifetime minimal Body Mass Index (BMI), scores of the Eating Attitude-Test (Garner et al., 1982) (EAT-26), Eating

Disorder Inventory (Garner et al., 1983) (EDI), and Beck Depression Inventory (Beck and Beamesderfer, 1974) (BDI), and age of first menses. Both parents accepted to participate in the study. Written informed consent was obtained from both parents and patients (probands). The study protocol was approved by the appropriate ethics committee (CCPPRB Bichat).

\section{Genotype detection}

Germline DNA was extracted from peripheral blood collected after the interview. DNA was isolated from leucocytes using standard salting out procedures (Miller et al., 1988). AgRP Ala67Thr (G/A), BDNF Val66Met (G/A) - SNP ID : rs6265 -, prepro-Ghrelin Leu72Met (C/A) - SNP ID : rs696217 - and prepro-Ghrelin Gln90Leu (A/T) - SNP ID : 
rs4684677 - polymorphisms were assessed using the ABI Prism 7000 Sequence Detection System (SDS) for multicolor real-time polymerase chain reaction (PCR) detection (Applied Biosystems, Courtaboeuf, France).

The primers and probe used for AgRP were design using Primer Express ${ }^{\circledR}$ software (Applied Biosystems, Courtaboeuf, France) and synthesized by Applied Biosystems using the context sequence:

ACCCTTGCTCACACTGACCTGGGAG[C/T]TCTGGGAGCAGGGCCTGGTCAGGCC.

The other SNPs detection were performed using TaqMan ® SNP Genotyping Assays. For BDNF: (forward primer): 5'-GCTTGACATCATTGGCTGACA-3', (reverse primer): 5'GGTCCTCATCCAACAGCTCTT-3' and (probe): 5'-[FAM]CTTTCGAACACGTGATAG-3' and 5' [VIC]CTITCGAACACATGATAG-3' (Applied Biosystems Assay ID : C_11592758_10). For prepro-Ghrelin:

Leu72Met : (forward primer): 5'-CGCTGCCACAGAAGCATAAAA, (reverse primer): 5'CCCGGAAGATGGAGGTCAA-3' and (probe): 5'-[FAM]CCGGACTTCCAGTTC-3' and 5' [VIC]CCCGGACTTCCATTT-3' (Applied Biosystems Assay ID : C__3151003_20). Gln90Leu : context sequence :

CAGGGCCTGGCTGTGCTGCTGGTAC[A/T]GAACCCCTGACAGCTTGATTCCAAC (Applied Biosystems Assay ID : C_25607748_10).

The thermal cycling conditions used were 2 minutes hold at $50^{\circ} \mathrm{C}$ followed by a 10 minutes hold at $95^{\circ} \mathrm{C}$ and then 40 cycles of $95^{\circ} \mathrm{C}$ for 15 seconds and $60^{\circ} \mathrm{C}$ for one minute. Repeatability of ABI Prism 7000 SDS genotyping was assessed by random reanalysis of a sub sample of DNA samples. Depending on the cohort and on the gene PCR success rates were: Sainte-Anne, AgRP: 97,3\%, BDNF: 99,1\%, prepro-Ghrelin Leu72Met : 97,3\%, 
prepro-Ghrelin Gln90Leu : 100\%; Robert Debré, AgRP: 97,5\%, BDNF: 99,1\%, preproGhrelin Leu 72Met : 98,3\% prepro-Ghrelin GIn90Leu : 99\%.

\section{Statistical analysis}

Polymorphisms were analysed using the transmission disequilibrium test (TDT, McNemar $\chi^{2}$ test (Spielman et al., 1993)). TDT analyses were performed for each polymorphism independently. P value assesses the significance of transmission distortion for specific haplotypes. Data were stratified by anorexia subtype (AN-R \& AN-BP) and Pearson's $\chi^{2}$ tests were carried out to investigate differences in allele frequencies according to center and clinical subtype ; t-tests were used to compare the clinical characteristics of carriers and noncarriers for each SNP. TDT was performed with an ad hoc EXCEL(C) spreadsheet (Microsoft France, Courtaboeuf, France) according to Spielman's work (Spielman et al., 1993), and p values < 0.05 were considered statistically significant. Linkage disequilibrium were tested using the SNPAlyze software (v5.1, Dynacom co., Ltd., Kanagawa, Japan). SYSTAT 11 (C) (Systat Software, Inc. Richmond CA, 2004) was used for all other statistical tests. 


\section{Results}

Genotypes and allele frequencies of the four SNPs followed Hardy-Weinberg equilibrium. Population heterogeneity among centers was excluded ( $p=0.79$ for prepro-ghrelin GIn90Leu, $p=0.46$ for prepro-ghrelin Leu72Met, $p=0.20$ for BDNF Val66Met and $p=$ 0.42 for AgRP Ala67Thr). Gln90Leu of the prepro-ghrelin gene is not in linkage disequilibrium with the Leu72Met polymorphism located in the same gene $\left(r^{2}=4.184^{\mathrm{E}}-3\right.$, $6.582^{\mathrm{E}}-3$, and $4.606^{\mathrm{E}}-3$ for probands, fathers and mothers respectively).

A transmission disequilibrium was observed for the Met72GHREL SNP and for the Thr67AgRP SNP (table 1). When stratified by clinical subtype, these polymorphisms were preferentially transmitted for the trios with a bingeing/purging proband. Transmission of preproghrelin haplotypes showed a transmission disequilibrium for the $90 \mathrm{Gln} 72 \mathrm{Met}$ haplotype (20 transmitted for 26 informative trios, $\chi 2=7.54, p=0.006$ ), preferentially for the ANB subtype (12 transmitted for 14 informative trios, $\chi 2=7.14, p=0.008$ ). The frequency of the Met72GHREL allele was doubled in the ANB group with respect to ANR $(\mathrm{OR}=2.26$, IC $95=0.95-5.37)$ and the proportions were reversed for the Leu90OBE allele $(\mathrm{OR}=0.42$, IC $95=0.08-2.17)$ (table 2$)$. No homozygous carriers for the Leu90OBE nor Thr67AgRP genes were observed. When comparing the clinical characteristics of the anorexic between carriers and noncarriers of each SNP (table 3), carriers of the obestatin GIn90Leu polymorphism (heterozygotes plus homozygotes), had a lower lifetime minimal BMI compared with the homozygotes for the wild allele (12.4 vs 13.6 for the wildtype, $p=0.025)$. An opposite difference was observed for Thr67AgRP carriers (15.1 vs 13.2 for the wildtype, $p=0.024$ ). Met72GHREL carriers and Met66BDNF carriers were associated with opposite statistically significant differences in the age of 
onset compared to the wildtype carriers ( 13.8 y vs 15.4 y for the Leu72GHREL wildtype, $p$ $=0.047$ and 16.0 y vs 14.5 y for the Val66BDNF wildtype, $p=0.047)$. Clinical severity, assessed by the EAT score, was higher in Met66BDNF carriers (32.6 vs 25.0 for the wildtype, $p=0.025$ ) and a lower sense of interpersonal distrust was associated with the Thr67AgRP allele, compared to the wild type (3.0 vs 6.1 for the wildtype, $p=0.002$ ). Clinical subtypes (i.e. ANR vs ANB) were statistically different for almost all clinical characteristics. Therefore, 2-way ANOVA were performed for each SNP (subtype vs allele variant). Except for the Leu90OBE polymorphism, all differences remained statistically significant ( $p=0.34,0.005,0.027,0.036,0.010$ and 0.006 respectively).

\section{Discussion}

This family-based analysis provides evidence for a preferential transmission of both the Leu72Met variant of the prepro-ghrelin gene and the Ala67Thr polymorphism of the AGRP gene, with, for the former, an excess of transmission of the Gln90Leu72 haplotype in patients with anorexia nervosa. Two recent articles (Cellini et al., 2006; Monteleone et al., 2006a) reported a lack of association of the Leu72Met variant of prepro-ghrelin with anorexia nervosa or bulimia nervosa, but a comparison between clinical subtypes of anorexia nervosa was not attempted in these two studies. We observed a preferential transmission and association of the Met72GHREL allele with the binge/purgeing subtype with a seemingly higher frequency of this allele compared to the restrictive subtype. Ethnic and international variations in the ghrelin gene polymorphisms have been reported (Ukkola et al., 2002; Cellini et al., 2006; Miyasaka et al., 2006) but the frequency of the 
Met72GHREL variant in our population is similar to the frequency observed in other european populations of anorexia nervosa - $11 \%$ of Met72GHREL allele compared to 6$10 \%$ in anorexia patients and 4-10 \% in control subjects - (Cellini et al., 2006; Monteleone et al., 2006a) and could not explain the differing results. Differences in the respective numbers of ANB and ANR enrolled in the anorexia nervosa populations may better explain this difference. At any rate, the functional significance of the Met72GHREL mutation remains uncertain : it lies outside the region where the mature ghrelin product is encoded (Kojima et al., 1999) but leucine at position 72 is highly conserved among the different mammalian species investigated sofar (Kaiya et al., 2001) and may play a significant role in posttranslational processing. Met72GHREL carriers in the general population display the lowest BMI and the lowest fat mass ; with less visceral fat and a lower fasting respiratory quotient, indicating a greater utilization of fat as an energy substrate (Ukkola et al., 2002). The Leu72Met substitution is also associated with an earlier age at onset of anorexia nervosa, as previously reported in obese subjects (Ukkola et al., 2001; Korbonits et al., 2002; Miraglia del Giudice et al., 2004).

The Leu90OBE variant was neither associated with anorexia nervosa nor with any subtype. On the contrary, there was a tendency for the Leu900BE allele not to be transmitted in the ANB subtype $(p=0.10)$. This SNP lies in the region coding for obestatin, a recently discovered peptide derived from the same ghrelin gene but having an opposite, anorexic, action(Zhang et al., 2005). Therefore, polymorphic variants of this gene might influence eating behavior. We did not correct for multiple testing for the TDT because we did consider each SNPs transmission as a separate hypothesis. This was strengthened by the absence of linkage disequilibrium between the Leu90OBE and the Met72GHREL SNPs. Because we separately compared the clinical characteristics between 
carriers and noncarriers for each SNP, the probability of having more than one statistically significant association is greater than the nominal $5 \%$ level. We eschewed methods to adjust for multiple comparisons (e.g., the Bonferroni correction) since they assume statistical independence among the comparisons and tend to be too conservative, hindering exploratory findings which are biologically plausible (Perneger, 1998). Confirmatory studies are then needed to confirm these exploratory findings about clinical associations with SNPs (Bender and Lange, 1999). Thus, a lack of adequate statistical power due to the low frequency of this allele and the limited sample size of our population may explain our results, but other studies in obesity and eating disorders also failed to find an association with this obestatin variant (Vivenza et al., 2004; Larsen et al., 2005; Steinle et al., 2005; Cellini et al., 2006). Noticeably, the european study found an association between the Leu90OBE polymorphism and AN in the german population whose control group showed a lower frequency of the Gln/Leu genotype compared to the combined spanish and italian controls ( $1.2 \%$ versus more than $7 \%$ for the other groups, (Cellini et al., 2006)). This low allele frequency in the control group was previously reported in a german study showing an association between this polymorphism and obesity but considered as a false positive association because a second control group of underweight students had the same Leu90OBE allele frequency (Hinney et al., 2002). Nevertheless, this last group had a significantly higher allele frequency than the normal weight control group and included some subjects with a clearly abnormal weight (mean BMI : $18.3+/-1.2 \mathrm{Kg} / \mathrm{m}^{2}$ ). The possibility of a common genotype vulnerability to obesity and $\mathrm{AN}$ remains to be explored.

The results of this study did not provide evidence for a preferential transmission of the 66Met allele of the BDNF. Case-control studies showed interpopulation variations ranging 
from no association with eating disorders in a german population (Friedel et al., 2005) and in a dutch population (de Krom et al., 2005), association with different subtypes of anorexia nervosa or bulimia nervosa in Spanish and Japanese samples (Ribases et al., 2003; Koizumi et al., 2004), to association with both eating disorders in a joint analysis of five European countries' populations (Ribases et al., 2004). This last study included a french population of 163 anorexics which showed an excess of Met66BDNF allele, especially in the ANB group, compared to a group of 510 control subjects including 56 French controls. If our population $(n=114)$ was to be compared to this control group, no association would have been observed. The frequency of healthy subjects carrying the Met66BDNF allele seems to differ widely from one country to another, being higher in japanese (41.1 \%) than in Italians (29.7\%) or Americans (18.0\%) (Shimizu et al., 2004), and a frequency of $15.2 \%$ has been observed in a Spanish control group (Ribases et al., 2003). Different methods have been proposed to correct for population stratification (Devlin et al., 2001) but an important advantage of the TDT is that it is largely protected from population stratification (Spielman et al., 1993). On the other side, this method is much less cost-effective than a case-control design (Gorwood, 1999). Our results are obviously limited by the relatively small number of family trios and a recent european family study including 453 trios also reports the association between anorexia nervosa and the Met66 allele (Ribases et al., 2005b). Several findings suggest that BDNF and its high affinity receptor TrkB contribute to food intake and body weight control. In rodents, genetic models with an altered BDNF/TrkB signalling display hyperphagia and obesity and pharmacological treatments with BDNF induce reduction in food intake (Hashimoto et al., 2005). Entire screening of the NTRK2 gene in eating disorder patients has revealed a strong association between certain haplotypes and ANB but failed to 
support the participation of epistatic effects between BDNF and NTRK2 in the risk to develop eating disorders (Ribases et al., 2005a). A recent study suggested that, while the 196G/A SNP of the human BDNF gene did not contribute to the genetic susceptibility to bulimia nervosa and binge eating disorder in their population, it may predispose these patients to a more severe binge eating behavior (Monteleone et al., 2006b). Implication of the Val66Met substitution in the pathophysiology of eating disorders remains unclear but this polymorphism has been shown to alter the intracellular trafficking and the regulated secretion of the mature BDNF (Lu, 2003).

Our results for the Ala67Thr AGRP polymorphism are in line with the case-control study of Vink et al. (Vink et al., 2001) which revealed an increased allele frequency in anorexia nervosa ( $6 \%$ compared to $2 \%$ in the control group). In the general population, homozygotous individuals for the Thr67AgRP variant allele, but not heterozygotous subjects, were found to have a lower weight, BMI, fat mass and leptin levels when compared to those carrying at least one Ala67AgRP allele (Marks et al., 2004). As AGRP is an endogeneous antagonist of hypothalamic melanocortin-4 receptor (MC4R) and stimulates feeding and weight gain, an alanine to threonine substitution at codon 67 might result in inadequate blockade of the MC4R with a consequently lower stimulation in food intake (Vink et al., 2001). But functional analysis of this polymorphism did not demonstrate a defect of Thr67AgRP related to MC4R interactions (de Rijke et al., 2005). Interestingly, in whites, Thr67AgRP heterozygotous display a lower self-reported intake of fats compared to Ala67Ala subjects (Loos et al., 2005). Anorexia nervosa is characterized by food avoidance and patients express fat aversion rather than carbohydrates fears (Drewnowski et al., 1988). 
The role of the mediobasal hypothalamus in food intake and energy regulation has progressed with the discovery of many neuropeptides/lipids and their cognate receptors (neuropeptide Y, AgRP, $\alpha-M S H, C A R T$, endocannabinoids), neurotrophic factors (BDNF, NT-3) and hormones (leptin, ghrelin, obestatin, PYY) which all impact on the intrahypothalamic regulation of body weight/feeding behaviour (Zigman and Elmquist, 2003). Further simultaneous analysis of genetic variants of these biological determinants of energy metabolism and feeding behavior in very large populations should contribute to the explanation of the high degree of heritability of eating disorders and to the description of pathophysiological patterns leading to life-threatening conditions in a highly redundant system.

Acknowledgements: This work was supported by grants from EC ('Factors in Healthy Eating') and INSERM. 


\section{REFERENCES}

American Psychiatric Association and American Psychiatric Association Task Force on DSM-IV, 1994. Diagnostic and statistical manual of mental disorders : DSM-IV. American Psychiatric Association, Washington, DC.

Beck, A. T. and Beamesderfer, A., 1974. Assessment of depression: the depression inventory. Mod Probl Pharmacopsychiatry 7, 151-69.

Bender, R. and Lange, S., 1999. Multiple test procedures other than Bonferroni's deserve wider use. BMJ 318, 600-1.

Cellini, E., Nacmias, B., Brecelj-Anderluh, M., Badia-Casanovas, A., Bellodi, L., Boni, C., Di Bella, D., Estivill, X., Fernandez-Aranda, F., Foulon, C., Friedel, S., Gabrovsek, M., Gorwood, P., Gratacos, M., Guelfi, J., Hebebrand, J., Hinney, A., Holliday, J., Hu, X., Karwautz, A., Kipman, A., Komel, R., Rotella, C. M., Ribases, M., Ricca, V., Romo, L., Tomori, M., Treasure, J., Wagner, G., Collier, D. A. and Sorbi, S., 2006. Case-control and combined family trios analysis of three polymorphisms in the ghrelin gene in European patients with anorexia and bulimia nervosa. Psychiatr Genet 16, 51-2.

de Krom, M., Bakker, S. C., Hendriks, J., van Elburg, A., Hoogendoorn, M., Verduijn, W., Sinke, R., Kahn, R. and Adan, R. A., 2005. Polymorphisms in the brain-derived neurotrophic factor gene are not associated with either anorexia nervosa or schizophrenia in Dutch patients. Psychiatr Genet 15, 81.

de Rijke, C. E., Jackson, P. J., Garner, K. M., van Rozen, R. J., Douglas, N. R., Kas, M. J., Millhauser, G. L. and Adan, R. A., 2005. Functional analysis of the Ala67Thr polymorphism in agouti related protein associated with anorexia nervosa and leanness. Biochem Pharmacol 70, 308-16. 
Devlin, B., Roeder, K. and Bacanu, S. A., 2001. Unbiased methods for population-based association studies. Genet Epidemiol 21, 273-84.

Drewnowski, A., Pierce, B. and Halmi, K. A., 1988. Fat aversion in eating disorders. Appetite 10, 119-31.

Friedel, S., Horro, F. F., Wermter, A. K., Geller, F., Dempfle, A., Reichwald, K., Smidt, J., Bronner, G., Konrad, K., Herpertz-Dahlmann, B., Warnke, A., Hemminger, U., Linder, M., Kiefl, H., Goldschmidt, H. P., Siegfried, W., Remschmidt, H., Hinney, A. and Hebebrand, J., 2005. Mutation screen of the brain derived neurotrophic factor gene (BDNF): identification of several genetic variants and association studies in patients with obesity, eating disorders, and attention-deficit/hyperactivity disorder. Am J Med Genet B Neuropsychiatr Genet 132, 96-9.

Garner, D. M., Olmsted, M. P., Bohr, Y. and Garfinkel, P. E., 1982. The eating attitudes test: psychometric features and clinical correlates. Psychol Med 12, 871-8.

Garner, D. M., Olmsted, M. P. and Polivy, J., 1983. Development and validation of a multidimensional eating disorder inventory for anorexia nervosa and bulimia. Int J Eating Disorders 2, 15-34.

Gorwood, P. (1999). Genetic association studies in behavioral neuroscience. Molecular Genetic Techniques for Behavioural Neuroscience. W. Cruzio and R. Gerlai. Amsterdam, Elsevier: 113-121.

Gorwood, P., Kipman, A. and Foulon, C., 2003. The human genetics of anorexia nervosa. Eur J Pharmacol 480, 163-70.

Hashimoto, K., Koizumi, H., Nakazato, M., Shimizu, E. and Iyo, M., 2005. Role of brainderived neurotrophic factor in eating disorders: recent findings and its 
pathophysiological implications. Prog Neuropsychopharmacol Biol Psychiatry 29, 499-504.

Hinney, A., Hoch, A., Geller, F., Schafer, H., Siegfried, W., Goldschmidt, H., Remschmidt, H. and Hebebrand, J., 2002. Ghrelin gene: identification of missense variants and a frameshift mutation in extremely obese children and adolescents and healthy normal weight students. J Clin Endocrinol Metab 87, 2716.

Hoek, H. W. and van Hoeken, D., 2003. Review of the prevalence and incidence of eating disorders. Int J Eat Disord 34, 383-96.

Kaiya, H., Kojima, M., Hosoda, H., Koda, A., Yamamoto, K., Kitajima, Y., Matsumoto, M., Minamitake, Y., Kikuyama, S. and Kangawa, K., 2001. Bullfrog ghrelin is modified by n-octanoic acid at its third threonine residue. J Biol Chem 276, 40441-8.

Klump, K. L. and Gobrogge, K. L., 2005. A review and primer of molecular genetic studies of anorexia nervosa. Int J Eat Disord 37 Suppl, S43-8; discussion S87-9.

Koizumi, H., Hashimoto, K., Itoh, K., Nakazato, M., Shimizu, E., Ohgake, S., Koike, K., Okamura, N., Matsushita, S., Suzuki, K., Murayama, M., Higuchi, S. and Iyo, M., 2004. Association between the brain-derived neurotrophic factor 196G/A polymorphism and eating disorders. Am J Med Genet B Neuropsychiatr Genet 127, 125-7.

Kojima, M., Hosoda, H., Date, Y., Nakazato, M., Matsuo, H. and Kangawa, K., 1999. Ghrelin is a growth-hormone-releasing acylated peptide from stomach. Nature 402, $656-60$.

Korbonits, M., Gueorguiev, M., O'Grady, E., Lecoeur, C., Swan, D. C., Mein, C. A., Weill, J., Grossman, A. B. and Froguel, P., 2002. A variation in the ghrelin gene increases 
weight and decreases insulin secretion in tall, obese children. J Clin Endocrinol Metab 87, 4005-8.

Larsen, L. H., Gjesing, A. P., Sorensen, T. I., Hamid, Y. H., Echwald, S. M., Toubro, S., Black, E., Astrup, A., Hansen, T. and Pedersen, O., 2005. Mutation analysis of the preproghrelin gene: no association with obesity and type 2 diabetes. Clin Biochem $38,420-4$.

Loos, R. J., Rankinen, T., Rice, T., Rao, D. C., Leon, A. S., Skinner, J. S., Bouchard, C. and Argyropoulos, G., 2005. Two ethnic-specific polymorphisms in the human Agoutirelated protein gene are associated with macronutrient intake. Am J Clin Nutr 82, 1097-101.

Lu, B., 2003. Pro-region of neurotrophins: role in synaptic modulation. Neuron 39, 735-8.

Marks, D. L., Boucher, N., Lanouette, C. M., Perusse, L., Brookhart, G., Comuzzie, A. G., Chagnon, Y. C. and Cone, R. D., 2004. Ala67Thr polymorphism in the Agoutirelated peptide gene is associated with inherited leanness in humans. Am J Med Genet A 126, 267-71.

Miller, S. A., Dykes, D. D. and Polesky, H. F., 1988. A simple salting out procedure for extracting DNA from human nucleated cells. Nucleic Acids Res 16, 1215.

Miraglia del Giudice, E., Santoro, N., Cirillo, G., Raimondo, P., Grandone, A., D'Aniello, A., Di Nardo, M. and Perrone, L., 2004. Molecular screening of the ghrelin gene in Italian obese children: the Leu72Met variant is associated with an earlier onset of obesity. Int J Obes Relat Metab Disord 28, 447-50.

Miyasaka, K., Hosoya, H., Sekime, A., Ohta, M., Amono, H., Matsushita, S., Suzuki, K., Higuchi, S. and Funakoshi, A., 2006. Association of ghrelin receptor gene 
polymorphism with bulimia nervosa in a Japanese population. J Neural Transm $113,1279-85$

Monteleone, P., Tortorella, A., Castaldo, E., Di Filippo, C. and Maj, M., 2006a. No association of the Arg51Gln and Leu72Met polymorphisms of the ghrelin gene with anorexia nervosa or bulimia nervosa. Neurosci Lett 398, 325-7.

Monteleone, P., Zanardini, R., Tortorella, A., Gennarelli, M., Castaldo, E., Canestrelli, B. and Maj, M., 2006b. The 196G/A (val66met) polymorphism of the BDNF gene is significantly associated with binge eating behavior in women with bulimia nervosa or binge eating disorder. Neurosci Lett 406, 133-7.

Nakazato, M., Murakami, N., Date, Y., Kojima, M., Matsuo, H., Kangawa, K. and Matsukura, S., 2001. A role for ghrelin in the central regulation of feeding. Nature 409, 194-8.

Nurnberger, J. I., Jr., Blehar, M. C., Kaufmann, C. A., York-Cooler, C., Simpson, S. G., Harkavy-Friedman, J., Severe, J. B., Malaspina, D. and Reich, T., 1994. Diagnostic interview for genetic studies. Rationale, unique features, and training. NIMH Genetics Initiative. Arch Gen Psychiatry 51, 849-59; discussion 863-4.

Otto, B., Cuntz, U., Fruehauf, E., Wawarta, R., Folwaczny, C., Riepl, R. L., Heiman, M. L., Lehnert, P., Fichter, M. and Tschop, M., 2001. Weight gain decreases elevated plasma ghrelin concentrations of patients with anorexia nervosa. Eur J Endocrinol $145,669-73$.

Perneger, T. V., 1998. What's wrong with Bonferroni adjustments. BMJ 316, 1236-8.

Ribases, M., Gratacos, M., Armengol, L., de Cid, R., Badia, A., Jimenez, L., Solano, R., Vallejo, J., Fernandez, F. and Estivill, X., 2003. Met66 in the brain-derived 
neurotrophic factor (BDNF) precursor is associated with anorexia nervosa restrictive type. Mol Psychiatry 8, 745-51.

Ribases, M., Gratacos, M., Badia, A., Jimenez, L., Solano, R., Vallejo, J., FernandezAranda, F. and Estivill, X., 2005a. Contribution of NTRK2 to the genetic susceptibility to anorexia nervosa, harm avoidance and minimum body mass index. Mol Psychiatry 10, 851-60.

Ribases, M., Gratacos, M., Fernandez-Aranda, F., Bellodi, L., Boni, C., Anderluh, M., Cavallini, M. C., Cellini, E., Di Bella, D., Erzegovesi, S., Foulon, C., Gabrovsek, M., Gorwood, P., Hebebrand, J., Hinney, A., Holliday, J., Hu, X., Karwautz, A., Kipman, A., Komel, R., Nacmias, B., Remschmidt, H., Ricca, V., Sorbi, S., Wagner, G., Treasure, J., Collier, D. A. and Estivill, X., 2004. Association of BDNF with anorexia, bulimia and age of onset of weight loss in six European populations. Hum Mol Genet 13, 1205-12.

Ribases, M., Gratacos, M., Fernandez-Aranda, F., Bellodi, L., Boni, C., Anderluh, M., Cristina Cavallini, M., Cellini, E., Di Bella, D., Erzegovesi, S., Foulon, C., Gabrovsek, M., Gorwood, P., Hebebrand, J., Hinney, A., Holliday, J., Hu, X., Karwautz, A., Kipman, A., Komel, R., Nacmias, B., Remschmidt, H., Ricca, V., Sorbi, S., Tomori, M., Wagner, G., Treasure, J., Collier, D. A. and Estivill, X., 2005b. Association of BDNF with restricting anorexia nervosa and minimum body mass index: a familybased association study of eight European populations. Eur J Hum Genet 13, 42834.

Shimizu, E., Hashimoto, K. and Iyo, M., 2004. Ethnic difference of the BDNF 196G/A (val66met) polymorphism frequencies: the possibility to explain ethnic mental traits. Am J Med Genet B Neuropsychiatr Genet 126, 122-3. 
Shuto, Y., Shibasaki, T., Otagiri, A., Kuriyama, H., Ohata, H., Tamura, H., Kamegai, J., Sugihara, H., Oikawa, S. and Wakabayashi, I., 2002. Hypothalamic growth hormone secretagogue receptor regulates growth hormone secretion, feeding, and adiposity. J Clin Invest 109, 1429-36.

Spielman, R. S., McGinnis, R. E. and Ewens, W. J., 1993. Transmission test for linkage disequilibrium: the insulin gene region and insulin-dependent diabetes mellitus (IDDM). Am J Hum Genet 52, 506-16.

Steinle, N. I., Pollin, T. I., O'Connell, J. R., Mitchell, B. D. and Shuldiner, A. R., 2005. Variants in the ghrelin gene are associated with metabolic syndrome in the Old Order Amish. J Clin Endocrinol Metab 90, 6672-7.

Sullivan, P. F., 1995. Mortality in anorexia nervosa. Am J Psychiatry 152, 1073-4.

Tanaka, M., Nakahara, T., Kojima, S., Nakano, T., Muranaga, T., Nagai, N., Ueno, H., Nakazato, M., Nozoe, S. and Naruo, T., 2004. Effect of nutritional rehabilitation on circulating ghrelin and growth hormone levels in patients with anorexia nervosa. Regul Pept 122, 163-8.

Tolle, V., Kadem, M., Bluet-Pajot, M. T., Frere, D., Foulon, C., Bossu, C., Dardennes, R., Mounier, C., Zizzari, P., Lang, F., Epelbaum, J. and Estour, B., 2003. Balance in ghrelin and leptin plasma levels in anorexia nervosa patients and constitutionally thin women. J Clin Endocrinol Metab 88, 109-16.

Tozzi, F., Thornton, L. M., Klump, K. L., Fichter, M. M., Halmi, K. A., Kaplan, A. S., Strober, M., Woodside, D. B., Crow, S., Mitchell, J., Rotondo, A., Mauri, M., Cassano, G., Keel, P., Plotnicov, K. H., Pollice, C., Lilenfeld, L. R., Berrettini, W. H., Bulik, C. M. and Kaye, W. H., 2005. Symptom fluctuation in eating disorders: correlates of diagnostic crossover. Am J Psychiatry 162, 732-40. 
Ukkola, O., Ravussin, E., Jacobson, P., Perusse, L., Rankinen, T., Tschop, M., Heiman, M. L., Leon, A. S., Rao, D. C., Skinner, J. S., Wilmore, J. H., Sjostrom, L. and Bouchard, C., 2002. Role of ghrelin polymorphisms in obesity based on three different studies. Obes Res 10, 782-91.

Ukkola, O., Ravussin, E., Jacobson, P., Snyder, E. E., Chagnon, M., Sjostrom, L. and Bouchard, C., 2001. Mutations in the preproghrelin/ghrelin gene associated with obesity in humans. J Clin Endocrinol Metab 86, 3996-9.

Vink, T., Hinney, A., van Elburg, A. A., van Goozen, S. H., Sandkuijl, L. A., Sinke, R. J., Herpertz-Dahlmann, B. M., Hebebrand, J., Remschmidt, H., van Engeland, H. and Adan, R. A., 2001. Association between an agouti-related protein gene polymorphism and anorexia nervosa. Mol Psychiatry 6, 325-8.

Vivenza, D., Rapa, A., Castellino, N., Bellone, S., Petri, A., Vacca, G., Aimaretti, G., Broglio, F. and Bona, G., 2004. Ghrelin gene polymorphisms and ghrelin, insulin, IGF-I, leptin and anthropometric data in children and adolescents. Eur J Endocrinol $151,127-33$.

Wajnrajch, M. P., Gertner, J. M., Sokoloff, A. S., Ten, I., Harbison, M. D., Netchine, I., Maheshwari, H. G., Goldstein, D. B., Amselem, S., Baumann, G. and Leibel, R. L., 2003. Haplotype analysis of the growth hormone releasing hormone receptor locus in three apparently unrelated kindreds from the indian subcontinent with the identical mutation in the GHRH receptor. Am J Med Genet A 120, 77-83.

Wren, A. M., Seal, L. J., Cohen, M. A., Brynes, A. E., Frost, G. S., Murphy, K. G., Dhillo, W. S., Ghatei, M. A. and Bloom, S. R., 2001. Ghrelin enhances appetite and increases food intake in humans. J Clin Endocrinol Metab 86, 5992. 
Zhang, J. V., Ren, P. G., Avsian-Kretchmer, O., Luo, C. W., Rauch, R., Klein, C. and Hsueh, A. J., 2005. Obestatin, a peptide encoded by the ghrelin gene, opposes ghrelin's effects on food intake. Science 310, 996-9.

Zigman, J. M. and Elmquist, J. K., 2003. Minireview: From anorexia to obesity--the yin and yang of body weight control. Endocrinology 144, 3749-56. 
TABLE 1 : Transmission dis equilibrium test (TDT) for the SNPs in informative trios

\begin{tabular}{|c|c|c|c|c|c|c|c|c|c|}
\hline & ANR & & & ANB & & & All & & \\
\hline SNPs & $\begin{array}{l}\text { Transmitted / } \\
\text { Nontransmitted }\end{array}$ & $\begin{array}{l}\text { Mc } \\
\text { Nemar } \\
\chi^{2}\end{array}$ & $p$ & $\begin{array}{l}\text { Transmitted / } \\
\text { Nontransmitted }\end{array}$ & $\begin{array}{l}\text { Mc } \\
\text { Nemar } \\
\chi^{2}\end{array}$ & $p$ & $\begin{array}{l}\text { Transmitted / } \\
\text { Nontransmitted }\end{array}$ & $\begin{array}{l}\text { Mc } \\
\text { Nemar } \\
\chi^{2}\end{array}$ & $p$ \\
\hline GIn90Leu - Obestatin & $5 / 7$ & 0.33 & 0.56 & $2 / 7$ & 2.78 & 0.096 & $7 / 14$ & 2.33 & 0.13 \\
\hline Leu72Met-Ghrelin & $8 / 4$ & 1.33 & 0.25 & $13 / 2$ & 8.07 & 0.005 & $21 / 6$ & 8.33 & 0.004 \\
\hline Val66Met - BDNF & $15 / 15$ & 0 & 1 & $10 / 13$ & 0.39 & 0.53 & $25 / 28$ & 0.17 & 0.68 \\
\hline Ala67Thr-AGRP & $6 / 3$ & 1 & 0.32 & $6 / 1$ & 3.57 & 0.059 & $12 / 4$ & 4 & 0.046 \\
\hline
\end{tabular}


TABLE 2 : Allele frequency according to clinical subtype (Restrictive - ANR - vs Bulimic/purgeing - ANB -)

\begin{tabular}{|c|c|c|c|c|c|c|c|c|c|c|c|c|}
\hline & OBE & & & GHR & & & BDNF & & & AGRP & & \\
\hline & $-90 G \ln$ & -90Leu & OR $[95 \% \mathrm{Cl}]$ & -72Leu & $-72 \mathrm{Met}$ & OR $[95 \% \mathrm{Cl}]$ & -66Val & -66Met & OR $[95 \% \mathrm{Cl}]$ & -67Ala & $-67 \mathrm{Thr}$ & OR $[95 \% \mathrm{Cl}]$ \\
\hline ANR n $(\%)$ & 114 & $6(5)$ & & 122 & $10(7.6)$ & & 102 & $30(22.7)$ & & 126 & $6(4.5)$ & \\
\hline ANB $n(\%)$ & 90 & $2(2.2)$ & $\begin{array}{l}0.42 \\
{[0.08-2.22]}\end{array}$ & 81 & $15(15.6)$ & $\begin{array}{l}2.26 \\
{[0.95-5.37]}\end{array}$ & 77 & $19(19.8)$ & $\begin{array}{l}0.84 \\
{[0.43-1.62]}\end{array}$ & 89 & $7(7.3)$ & $\begin{array}{l}1.65 \\
{[0.53-5.20]}\end{array}$ \\
\hline
\end{tabular}


TABLE 3 : Phenotypic characteristics of probands associated with each SNP

\begin{tabular}{|c|c|c|c|c|c|c|c|c|c|c|c|c|}
\hline & OBE & & & GHR & & & BDNF & & & AGRP & & \\
\hline & $\begin{array}{l}- \\
(n=98)\end{array}$ & $\begin{array}{l}+ \\
(n=8)\end{array}$ & $p$ & $\begin{array}{l}- \\
(n=91)\end{array}$ & $\begin{array}{l}+ \\
(n=23)\end{array}$ & $p$ & $\begin{array}{l}- \\
(n=70)\end{array}$ & $\begin{array}{l}+ \\
(n=44)\end{array}$ & $p$ & $(n=101)$ & $\begin{array}{l}++ \\
(n=13)\end{array}$ & $p$ \\
\hline $\begin{array}{l}\mathrm{Nb} \text { of restrictive subtype } \\
(\%)\end{array}$ & $54(55.1)$ & $6 \quad(75.0)$ & ns & $57 \quad(62.6)$ & $9 \quad(39.1)$ & ns & 39. $(57.7)$ & 27. $(61.4)$ & ns & $60 \quad(59.4)$ & 6. $(46.2)$ & ns \\
\hline Age of Onset (SD) & $15.3(4.0)$ & $13.9(3.6)$ & ns & $15.4(4.1)$ & $13.8(3.3)$ & 0.047 & $14.5(3.8)$ & $16.0(4.0)$ & 0.047 & $15.0(3.5)$ & $15.7(6.5)$ & ns \\
\hline Age at first menarches & $12.9(1.4)$ & $12.4(1.7)$ & ns & $12.8(1.4)$ & $13.1(1.5)$ & ns & $12.7(1.3)$ & $13.2(1.6)$ & ns & $12.9(1.5)$ & $12.4(1.2)$ & ns \\
\hline Minimum BMI & $13.6(2.1)$ & $12.4(1.3)$ & 0.025 & $13.5(2.2)$ & 13.4 & ns & $13.4(2.2)$ & $13.5(2.0)$ & ns & $13.2(1.9)$ & $15.1(2.5)$ & 0.024 \\
\hline
\end{tabular}

